\title{
Discipline of Teaching English as an International Language - D-TEIL: perspectives for language teacher education
}

\section{Discipline of Teaching English as an International Language - D-TEIL: perspectivas para a formação de professores de línguas}

Discipline of Teaching English as an International Language - D-TEIL: perspectivas para una formación de profesores de lenguas

Gustavo Moura ${ }^{1}$

Brian Morgan²

DOI: http://dx.doi.org/10.20435/serie-estudos.v25i54.143

\begin{abstract}
The role international practicum placements have in the professional development of language educators is a contentious issue, with not all researchers in agreement that international practica are necessarily natural, neutral, or beneficial, to borrow from Pennycook's (2007, 2012, 2017) stance on English language teaching internationally. Scholars like Santoro (2007, 2009), for instance, have expressed concern that international practica constitute a little more than a form of educational tourism that is potentially exploitative of the host communities. However, some program developers and researchers acknowledge and prioritize the value-laden and sociopolitical nature of practice teaching abroad and strive to facilitate ethical and critical practices (MORGAN; MARTIN, 2014; MARTIN; MORGAN, 2015, 2019). For that reason, this paper critically analyzes crossing borders with reference to the D-TEIL certificate program. The outcomes of an international practicum experience suggest changes towards considering the multiplicity of knowledge and aim at developing strategies for language teacher education programs towards ethical practices.
\end{abstract}

Keywords: international practicum; English language teaching; ethical practices.

Resumo: O papel que os estágios internacionais têm no desenvolvimento profissional de professores de línguas é uma questão contenciosa, visto que nem todos os pesquisadores concordam que estágios internacionais são necessariamente naturais, neutros ou benéficos, de acordo com a posição de Pennycook $(2007,2012$, 2017) em relação ao ensino de língua inglesa em

\footnotetext{
1 University of Manitoba, Winnipeg, Canada.

2 Glendon College, York University, Toronto, Canada.
} 
contexto internacional. Pesquisadores como Santoro (2007, 2009), por exemplo, expressaram a preocupação de que estágios internacionais constituem uma forma de um turismo educacional que potencialmente explora comunidades anfitriãs. No entanto alguns outros desenvolvedores desses programas e também pesquisadores reconhecem e priorizam o valor e a natureza sociopolítica de se ensinar no exterior, assim como lutam para facilitar práticas éticas e críticas (MORGAN; MARTIN, 2014; MARTIN; MORGAN, 2015). Por essa razão, este artigo analisa criticamente o atravessar fronteiras com referência ao programa de certificação D-TEIL. Os resultados de uma experiência de estágio internacional sugerem mudanças para se considerar a multiplicidade de conhecimento e objetivam o desenvolvimento de estratégias para os programas de formação de professores de língua inglesa em direção a práticas éticas.

Palavras-chave: estágio internacional; ensino de língua inglesa; práticas éticas.

Resumen: El papel que tienen las prácticas internacionales en el desarrollo profesional de los educadores de idiomas es un tema polémico, ya que no todos los investigadores están de acuerdo de que las prácticas internacionales son necesariamente naturales, neutrales o beneficiosas, para tomar prestada la postura de Pennycook $(2007,2012,2017)$ sobre la enseñanza de inglés a nivel internacional. Los académicos como Santoro (2007, 2009), por ejemplo, han expresado su preocupación de que la práctica internacional constituya un poco más que una forma de turismo educativo que es potencialmente explotador de las comunidades de acogida. Sin embargo, algunos desarrolladores e investigadores del programa reconocen y priorizan la naturaleza cargada de valor y sociopolítica de la práctica de la enseñanza en el extranjero y se esfuerzan por facilitar las prácticas éticas y críticas (MORGAN; MARTIN, 2014; MARTIN; MORGAN, 2015, 2019). Por esa razón, este documento analiza críticamente el cruce de fronteras con referencia al programa de certificado D-TEIL. Los resultados de una experiencia práctica internacional sugieren cambios para considerar la multiplicidad de conocimiento y apuntan al desarrollo de estrategias para programas de formación de profesores de idiomas hacia prácticas éticas.

Palabras clave: pasantía internacional; enseñanza de lengua inglesa; prácticas éticas.

\section{INTRODUCTION}

Having in mind pre-service teachers are getting prepared to work with learners from a globally interdependent world, it is pivotal to understand how international practicum experiences inform language teacher education (LTE). LTE curricula, accordingly, need revisiting strategies for educators to integrate a global perspective within their own practices, even if local teaching settings still look at one-size-fits all approaches of teaching methods (e.g.: audiolingual, grammar focused), for example. Sensibly, LTE should predominantly contribute to independent decision-making processes, as much as it prepares future teachers to be globally minded professionals who can deal with the diverse assets of a culturally hybrid society (KISSOCK; RICHARDSON, 2010; DOOLY; VILLANUEVA, 2006; MCCARTNEY; HARRIS, 2014). 
Particularly, to what concerns internationalization, higher education institutions have invested in partnerships overseas to promote international practica (KISSOCK; RICHARDSON, 2010; MARTINEZ, 2017; MCCARTNEY; HARRIS, 2014). However, a gap in curricula permeates the preparation of pre-service teachers in the most varied fields of education. This gap specifically refers to the fact that the course requirements and materials for LTE often attend to dominant and normalized standards of teaching with the assumption that the values, morals and ethics underpinning their locality would comparably apply in different countries of the world.

Although a few educational institutions offer options for pre-service teachers to explore a different culture before they land in another country, in the majority of cases, teachers are blindly getting themselves involved in a different world. By that, we can comment on paradigmatic values related to methodology, perhaps arguing that most LTE programs still work from an epistemological assumption that a one-size-fits-all, best method (say, Communicative Language Teaching at this time) exists, requiring only limited or superficial attention to culture - or restricted, congruent forms of interculturality on terms dictated by the Global North (KUMARAVADIVELU, 2012). Addressing this assumption or epistemological/ pedagogical gap in LTE has been a central organizing principle for the Certificate Program in the Discipline of Teaching English as an International Language (D-TEIL) at Glendon College in Toronto. Within D-TEIL, it is only when we attend to Kumaravadivelu's (2012) parameters and post-methods that attention to (sociocultural and economic) particularities becomes critical.

When LTE programs integrate experiences that go beyond their national boundaries, they effectively integrate different views of society, reshape teacher identities, and foster global citizenship (MARTIN; MORGAN, 2015, 2019; KISSOCK; RICHARDSON, 2010; MARTINEZ, 2017). However, a cross-cultural experience must be well designed in order to offer pre-service teachers the necessary tools for navigating on stranger tides. International practica are relatively new to (language) teacher education programs, and because of that, they need constant reflection as global flows are constantly changing and requiring new positionalities from global citizens.

For the LTE field, it is important to highlight that through international practica, participants - coordinators of programs, students and teachers - return 
from the host countries with different types of knowledges and experiences. International practitioners contribute to the development of a global knowledge, and indeed, global knowledge informs future practica and research. With respect to teaching pedagogies and educational philosophies, international teaching provides teachers and teacher educators with a self-awareness which allows them to make decisions and (re)develop their own principles of teaching.

The focus on English language teaching, in this paper, allows educators and teacher educators to reconcile their views and other scholars' contributions on rethinking the role of English as a world language (JENKINS, 2003; PENNYCOOK, 2007; MCKAY; BOKHORST-HENG, 2008; MARTIN; MORGAN, 2015, 2019) as well. As a world language, English serves different nation-states and cultures in several different ways, and as language educators, it is critical to raise consciousness to how English patterns work in different cultures and how complex the forms of motivation to learn the language can be.

\section{BORDER CROSSING: TIME TO RETHINK SOCIAL SPHERES}

Border crossing entangles different concepts within today's society, and from cognitive to social and cultural concepts, it requires navigation through different perspectives. On the one hand, as Giroux (1992) defends, border crossing is a cognitive process that allows individuals to go beyond dominant ideals of practices and states of knowledge. As if it were a state of mind, border crossing means to expand one's views over fixed knowledges. Border-crossing also means to revisit and see that there are different ways of knowing as much as there are cultural factors which allow knowledge to be fluid and changeable (GIROUX, 1992). On the other hand, beyond cognitive habits and ideologies, Cushner and Brennan (2007) associate border-crossing with the importance of international collaboration within a globalized society. That means, from an educational context, overseas student teaching has the potential influence to strengthen social and (inter)cultural competency of teacher educators and pre-service teachers.

Still, the outcomes of border crossing can be either emancipatory or exploitative, and sometimes both. Regarding the former, the borders crossed may be paradigmatic in scale - encompassing epistemologies, values and practices of the oppressed (FREIRE, 1997; MACIEL, 2011) that were previously ignored or stigmatized by the powerful. Such transformative possibilities are reflected in 
the recent exploration of indigenous (KASUN; SAAVEDRA, 2016) and ecological perspectives in LTE (APPLEBY, 2017; GUERRETTAZ; JOHNSTON, 2013; MORGAN; MARTIN, 2014). Yet, as suggested above, these "new" knowledge systems can also be used to contain and coopt the differences they reveal.

One example of current relevance can be found in the rush towards greater internationalization in universities and colleges (see e.g. MARTINEZ, 2017), particularly in inner circle/centre-based nation-states, where the revenue generated from relatively high, foreign tuition fees compensate, in part, for a steady decline in government funding within broader social contexts of antiintellectualism and neoliberal accountability imposed on education in general. This is indeed the paradox of border crossing in current times: on the one hand, generating superficial and commoditized notions of diversity, yet on the other, enabling a genuine desire for more horizontal relationships, especially amongst today's globally networked youth, for whom international practica may appeal to a sense of purpose and belonging that extend beyond local and nation-state allegiances (a key point raised by Cushner and Brennan [2007]).

According to Cushner and Brennan (2007, p. 58), a few of the outcomes of international practica, for instance, reflect "enhancing language and communication skills, increasing flexibility or open-mindedness, developing an ability to empathize or understand the position of the other, and a beginning recognitions of other value systems and ways of behaving". Interculturally, according to Cushner and Brennan (2007), practitioners who go abroad to teach develop more critical and political knowledge towards the culture which hosts them. In the field of English language teaching, for instance, intercultural competence is an asset for teachers who often deal with a diverse group of people who aim at learning English as either a foreign or additional language. Teaching abroad fosters the autonomy and enhances intercultural awareness of those who cross political and national borders to teach (WALTERS; GARII; WALTERS, 2009; PARR, 2012; MOTHA, 2014; GONZÁLESCARRIEDO; MARTÍNEZ, 2017). Consequently, study-abroad participants have an advantage in accurately and ethically being able to respond to cultural issues as host countries usually allow them to experience and reshape empathy, understanding, and tolerance. And for this point, we would add that the "advantage" is a potential or affordance that is made available through the right conditions and preparation by the LTE program (i.e. D-TEIL) and the practicum hosts. 
As for empathy, understanding, and tolerance, Giroux (1992) puts at stake a sphere where equality, justice, and freedom are core to understanding a new culture of work. Regarding teachers, specifically, pedagogy is essential to the breach of conventional views of schooling and education nowadays. That means knowledge construction represents and is implicated by the dynamics of social power that are underestimated and naturalized in teaching practices. The conventional teaching of methods, for instance, has paid little attention to a politics of cultural differences, which reduces any chance of challenging conventionality.

Indeed, schooling is crucial for educating critical citizens who are responsible for exercising leadership within a democratic society. However, the focus of research should contemplate more than the spaces where schooling happens. More broadly, researchers should start rethinking beyond teacher education, public elementary and high-schools, and higher education. That is, schools alone cannot change and resolve all issues of society. Moreover, structural and ideological dynamics of power tend to reproduce existing norms and social hierarchies through curricular practices. And education is one of the many aspects in which traditional teaching has emphasized boundaries in disciplines, reinforcing hegemonic paradigms. An example of this would be the return to phonics literacy in Brazil and sometimes decontextualized learning (FERRAZ, 2018).

The discussions around hegemonizing paradigms in education challenge the view of teaching as ideologically and politically neutral. Language, for example, has worked as instrumental in the determination of purposes of teaching, and therefore, fortified the privilege of certain dominant groups of elites (GIROUX, 1992; PENNYCOOK, 2007). Today's English language teaching, unfortunately, still presents a scenario where white, upper-middle-class individuals silence and subordinate whoever does not attend to those features. Thus, it is essential to be aware of those realities in schools as much as schools should deal with them so that individuals can exercise the transformation outside schools as well.

Nowadays, the awareness teachers and students need in schools reflects the vast flow of information and mobility of people around the world. The modernization of the West, and its dominance in global economic decisionmaking marks a new configuration in power, patriarchy, authority and ethics. The concept of progress, through scientific and technological innovation and enhanced productivity, has become both the goal and measure of this modernization and the 
legitimized knowledge forms supporting it. As an inheritance of the Enlightenment traditions, as Giroux (1992) assumes, the legitimation of Western culture as models of thinking, acting, and behaving represent a struggle in democracy. Although democratization is claimed within the modernization of the world, there is little space to challenge hegemonic domains and practices. Given this challenge, Giroux (1992) sees the concept of border crossing - whether epistemological, pedagogical, ideological, in form - as an essential activity for educators and cultural workers concerned with social justice. Towards this goal, universities serve as key sites for the types of identity negotiation and teacher agency that crossing borders suggests and innovative curricula make available. Such curricula would engage students with borders both virtual and real, involving information flows on social media (i.e., critical multiliteracies) but also awareness of nation-state policies and practices impacting on the life chances of students (i.e., critical citizenship pedagogies).

The way in which crossing borders works in today's society is relevant to rethinking what people who are crossing borders are doing, why they are doing it, and how they are doing it. From a critical perspective, although creating new social spheres and reshaping knowledge as encounters with different ways of knowing may benefit democratic practices, it would rather be better to beware if all migrations are not, in fact, contributing to the hegemonizing of colonial and conventional politics as is the case of native speakerism, for instance. In the case of language teaching, more studies have contributed to demystifying the notion of authenticity of native speakerism (GIROUX, 1992; MCKAY; BOKHORST-HENG, 2008; PENNYCOOK, 2007; ROCHA; MACIEL, 2013; MENEZES DE SOUZA, 2017), for example.

Pennycook (2007), specifically, claims transgressive practices should include critical, social inquiry on the differences within and between English-speaking communities. Transgressive in this context, would also mean questioning patterns and standards of teaching which consolidates role models of teaching that are not context-sensitive. In the case of the D-TEIL program, we see this notion of transgression in how participants are encouraged to question and challenge the validity and neutrality of standard languages, opening up spaces for integrating World Englishes and English as a Lingua Franca in LTE curricula, not to mention plurilingual orientations. The world is far too diverse to set parameters for 
a standardized, inner circle variety of English to be spoken (OCHOA, 2010); hence there is a need to comprehend how cultural flows have reshaped the understanding of English language teaching and its impact in social contexts today through students teaching abroad.

\section{STUDENT TEACHING ABROAD: D-TEIL}

Within their own localities, teacher education programs seek to provide pre-service teachers with authentic experiences of the advantages and pitfalls of a teaching career by having student-teachers facing classrooms themselves. However, in the last couple of decades, international teaching practica have gained special attention since they provide enriched experiences and possibilities for perspectival change in teaching and teacher education (KISSOCK; RICHARDSON, 2010; CHAN; PARR, 2013; MATSUDA, 2017). Lately, international practica for teachers have shown themselves to be a growing strategy for educational institutions, which aim at placing their pre-service teachers in other countries and cultures, and that look forward to the developing foundational perspectives on global teaching and living.

Student teaching abroad has been interpreted and implemented in a variety of ways. We find scholars who say that travelling on your own increases/ enhances intercultural exchanges (KISSOCK; RICHARDSON, 2010; HOLLIDAY, 2009), whereas others claim that travelling in a group tends to reduce your need to negotiate new linguistic and cultural domains. Adding to the benefits of an international practicum, studies point out that those who participate in teaching abroad programs have their personal and professional experiences reach a good level of self-efficacy (KISSOCK; RICHARDSON, 2010; PARR, 2012; MOTHA, 2014; GONZÁLES-CARRIEDO; MARTÍNEZ, 2017). Besides, teaching internationally contributes to the pluricultural education of both pre-service teachers and students. Their interaction with people from different ethnic groups and cultural backgrounds is an important index of new paths of learning how to be/become a citizen of the world.

Additionally, the practicum overseas is both relevant and appropriate. It gives new teachers an idea of what it means to teach and includes aspects of diversity within teaching practices. Once returning to the country of origin, teachers can use their international experiences to inform their classroom practices. Basically, 
an international practicum infers a notion of readiness to deal with difficult and unexpected cultural circumstances. Living across cultural boundaries allows pre-service teachers to perceive flexibility as fundamental to the tolerance of the existence of ambiguity and to the understanding of cultural differences (CUSHNER; BRENNAN, 2007).

From a collaborative international attitude, teaching abroad also promotes the deconstruction of ethnocentrism and its preconceptions of the culture of the other. The ones involved in the process of teaching abroad construct an awareness around effective communication across cultures and start realizing the implications of cultural forms in the way people talk, act, and behave. Along with this enhanced cultural awareness, teachers' interpersonal skills benefit from the cultural border crossing, and surely the cultural shock helps the pre-service teachers to realize what it means to go through international transitions. In order to provide more detail on student teaching abroad programs, this paper is focused on the analysis of the D-TEIL program partaken in 2016 by researchers from Brazil and Canada, and a group of student-teachers from Canada.

\section{CERTIFICATE PROGRAM IN THE DISCIPLINE OF TEACHING ENGLISH AS AN INTERNATIONAL LANGUAGE (D-TEIL): OVERVIEW}

The D-TEIL certificate is offered by the English Department at York University/ Glendon College in Toronto, Ontario. Its purposes include learning about different cultures and languages as part of a liberal arts education and working with students who show interest in the field of teaching English as an international language. The D-TEIL certificate ${ }^{3}$ offers student-teachers the chance to deal with the general principals of linguistics applicable to language teaching, the notions of language learning, the concepts of language and society and bilingualism, as well as the history and impact of English as a global language.

Successful completion of the certificate includes participation in an international practicum, which provides graduates with both teaching experience and newfound confidence if they wish to seek out EIL teaching opportunities abroad. As the program proposes, the practicum normally takes place in an

3 For D-TEIL certificate program requirements see: https://www.glendon.yorku.ca/english-studies/ dteil/ 
international setting and is an essential component of the certificate. Through a partnership with a Cuban university, the E. A. Varona Pedagogical University in Havana, the Canadian institution has signed an agreement which allows students coming from Canada to participate in a three-week teaching opportunity on the Cuban campus. The exchange agreement supports the mutual collaboration of both universities, and in the past few years, this relationship has been strengthened with the addition of Brazilian academics in the project.

Regarding practicum expenses, the Canadian university offers travel awards for institutional students. The bursary does not cover the whole cost of the trip, which requires D-TEIL students to also organize themselves in order to promote fundraising activities which help with the costs of the trip. The coordinator of the program always makes sure students are able to attend this practicum, since for some of the new student-teachers, this could be their only opportunity to experience international teaching and learn from another culture.

In 2016, we were a group of 16 pre-service teachers, one master's student and one PhD student, and four researchers/professors (2 Canadian and 2 Brazilian). We stayed in Cuba for a total of twenty-three days. In three weeks, our practicum had been divided as: week 1 - student-teachers meet their designated group of students and observe the classes; week 2 - student-teachers meet their classroom teachers/local supervisors and plan a lesson collaboratively; and week 3 -studentteachers, on their own, teach a lesson whose planning had happened while they were still in Canada. For the last week of the practicum, pre-service teachers had to choose a topic of interest and develop a language lesson or unit around it. Some of the topics varied among ballet dancing, graffiti, hip hop, vegetarianism and many others.

Within the last week of practicum, the selection of a topic and its realization as a lesson for Cuban students worked as an exercise to develop intercultural awareness among teachers and students from the different countries. This activity was an exemplary opportunity for creating and enhancing new understandings around language teaching and changing perspectives of practices that seem culturally neutral. 


\section{PERSPECTIVES FOR LANGUAGE TEACHER EDUCATION: D-TEIL LESSONS}

Among the various themes that emerge from the experience with the D-TEIL, we emphasize: enhancing students' learning, critiquing native speakerism, or the type of English one speaks (e.g.: British or American English?), and creating pedagogical strategies, observational skills, teacher's agency and the overall impact of culture in teaching.

To what concerns students' learning, Santoro $(2007,2009)$ affirms that teacher education programs should include tools which allow pre-service teachers to properly deal with their students. Generally, pre-service teachers are not fully aware of who their students are. To really know who their students are, teacher educators and pre-service teachers ought to learn about the host community beyond the classroom. That is, there should be an understanding of students' local histories, the cultural backgrounds they have, and more importantly, a comprehension that their identities are socially and historically constructed.

Secondly, regarding native speakerism, pre-service teachers need to be aware of the potential limitations of the teacher who is an English-native speaker. Martin and Morgan (2015, 2019), for instance, present some participants' observations during their practicum in Cuba, which state that non-native speakers of the language are indeed able to master the descriptive and pedagogical knowledge of the language. The myth of a so-called English native-speaker as the ideal teacher has failed in terms of providing efficacy in teacher and student interactions, and consequently in the development of students in language classes. Moura (2017), as an English as a foreign language speaker, notes that becoming a teacher in international settings goes beyond the knowledge of the language system. In fact, the role of a teacher educator as a non-mainstream, English native-speaker encourages different types of understandings as society is culturally and socially fluid.

This native speakerism theme aligns with a third theme, which seeks the dismantling of the types of English one can speak. Often, in language courses, learners are curious to know whether they will be learning American or British English. Pre-service teachers who come from contexts that are not the US or Great Britain generally face the simple question of which dominant variety (e.g., American or British English) they plan to teach. Providing a broad cultural perspective on the different Englishes in the world (JENKINS, 2003; PENNYCOOK, 2007, 2017; KIRKPATRICK, 2006) actually contributes to pre-service teachers' 
self-awareness that identities are shaped through the language. Hence, American and British Englishes are not the only forms to sustain who you are through what you speak. The localities of the individuals carry out with the shaping of their identities and that should be celebrated, rather than marginalized and fitted into the dominant language teaching boundaries.

Next, considering pedagogical strategies, informing practices do not exclusively relate to the teaching of the systems of a language. Nor is it all about critically analyzing cultural and social factors in which the teaching takes place. Language teacher education programs should find a balance in fostering openmindedness towards the culture of the other as much as understanding what language teaching means. The D-TEIL program courses are a great example Martin and Morgan $(2015,2019)$ found to compile different knowledge around teaching methodologies, pedagogies, and cultural awareness. Yet, according to the scholars, they are preparing teachers to responsibly understand their counterparts in different countries.

Allowing students to notice the importance of observational skills as they inform themselves about the history and locality of the host country is another fundamental attitude language education programs should consider. Observations enhance teacher agency, and the decision-making processes are better informed when teachers are aware of what happens to students in the language learning process. The intercultural experience allows future teachers to walk into their classrooms more able to attend to their students. Language teaching is now a source of awakening future teachers to see and respond to their students in a culturally and globally aware manner. Teaching should be both contextual and interdependent, as much as it should be participatory. We need to remember that the ELT field is changing to reflect the changing role of English(es) in the world. Language teacher education programs are directly implicated in this process.

\section{CONCLUSION}

The key responsibility of teacher educators is preparing global teachers to deal with global citizens. Although, researchers like Santoro $(2009,2012)$ state that some teachers are not well prepared to teach students whose cultural values and beliefs are different from the mainstream, that does not mean teachers educators and new teachers are not attempting to change that view. Teacher educators need 
to reflect critically on the ethics of international practica (KISSOCK; RICHARDSON, 2010; SANTORO; MAJOR, 2012), and some of the critical responsibilities of teacher educators may include:

1) embracing global perspectives: which means understanding the value of learning from differences, and integrating global perspectives which associate and negotiate several perspectives in a local context;

2) adopting and achieving both local and global (i.e., glocal) standards: that is, working towards the divergence of standards from a local perspective means to recognize and adopt locally appropriate ways of teaching. A global perspective is an ethical one where expertise is horizontally shared and not imposed from the so-called inner circle of the English language teaching industry.

3) serving our global village: as teacher educators open up possibilities for preservice teachers to experience other cultural societies, this type of experience employs global skills in them, therefore new teachers are being prepared to face global issues in different and creative other forms; and,

4) working toward the broadening of students' perspectives: as students will reflect on the future of the world and develop their own paths throughout their journey.

Preparing pre-service teachers to teach internationally involves much more than a practicum in which they go abroad with prepackaged language plans, learning objectives and evaluation activities. Language teachers are dealing with different cultures that expect something from them, and the sense of responsibility to the culture of the other should be exercised (MCCARTNEY; HARRIS, 2014). By that, we mean nurturing reflective practitioners who can see they are responsible for new strategies of teaching which recognize that host countries actually have a lot to offer for those who are border crossing.

\section{REFERENCES}

APPLEBY, R. Dealing with controversial findings. In: ROSE, H.; MCKINLEY, J. (Ed.). Doing research in applied linguistics: realities, dilemmas and solutions. New York and London: Routledge, 2017.

CHAN, J.; PARR, G. Intercultural teacher education: challenges and ethical dilemmas on an international practicum. In: AUSTRALIAN ASSOCIATION FOR RESEARCH IN EDUCATION [International Conference], Sidney, 2012. December 2013. DOI: 10.13140/2.1.3319.3765 
CUSHNER, K.; BRENNAN, B. The value of learning to teach in another culture. In: CUSHNER, K.; BRENNAN, S. (Ed.). Intercultural student teaching: a bridge to global competence. Plymouth: Rowman \& Littlefield Education, 2007.

DOOLY, M.; VILLANUEVA, M. Internationalisation as a key dimension to teacher education. European Journal of Teacher Education, [S.I.], v. 29, n. 2, p. 223-40, 2006.

FREIRE, P. Educação como prática de liberdade. Rio de Janeiro: Paz e Terra, 1997.

GIROUX, H. A. Border crossings: cultural workers and the politics of education. New York: Routledge, 1992.

GONZÁLEZ-CARRIEDO, R.; MARTÍNEZ, M. S. International student teaching: a transformational experience. Journal of International Students, v. 7, n. 3, p. 842-55, 2017. Available at: https://zenodo.org/record/570037\#.XukN40VKg2w. Access on: 16 June 2020.

GUERRETTAZ, A.; JOHNSTON, B. Materials in the classroom ecology. Modern Language Journal, [S.I.], v. 97, n. 3, p. 779-96, Aug. 2013. DOI: https://doi. org/10.1111/j.1540-4781.2013.12027.x.

HOLLIDAY, A. English as a Lingua Franca, 'non-native speakers' and cosmopolitan realities. In: SHARIFIAN, F. English as an international language. Bristol, UK: Multilingual Matters, 2009.

JENKINS, J. World Englishes: a resource book for students. New York: Routledge, 2003.

KASUN, G.; SAAVEDRA, C. Disrupting ELL teacher candidates' identities: indigenizing teacher education in one study abroad program. TESOL Quarterly, [S.I.], v. 50, n. 3, p. 684-707, Sept. 2016. DOI: https://doi.org/10.1002/tesq.319.

KIRKPATRICK, A. Which model of English: native-speaker, nativized, or lingua franca? In: RUBDI, R.; SARACENI, M. (Ed.). English in the world: global rule, global roles. London: Continuum, 2006.

KISSOCK, C.; RICHARDSON, P. Calling for action within the teaching profession: It is time to internationalize teacher education. Teaching Education, [S.I.], v. 21, n. 1, p. 89-101, 2010.

KUMARAVADIVELU, B. Language teacher education for a global society: a modular model for knowing, analysing, recognizing, doing and seeing. New York: Routledge, 2012.

MACIEL, R. F. From innovation to language policy: towards a locus of research in Applied Linguistics. In: MACIEL, R. F.; ARAÚJO, V. A. (Org.). Formação de professores de línguas: ampliando perspectivas. Jundiaí, SP: Paco Editorial, 2011. 
MARTIN, I.; MORGAN, B. A transnational approach to language teacher education: the Glendon D-TEIL experience in Cuba and Brazil. In: MAGNO E SILVA, W.; SILVA, W. R.; CAMPOS, D. M. (Org.). Desafios da formação de professores na linguística aplicada. Campinas, SP: Pontes Editores, 2019.

MARTIN, I.; MORGAN, B. Preparing teachers for 'unequal Englishes': the D-TEIL experience in Cuba. In: TUPAS, R. (Ed.). Unequal Englishes. London: Palgrave Macmillan, 2015.

MARTINEZ, J. Z. Entre fios, pistas e rastros: os sentidos emaranhados da internacionalização da educação superior. 2017. Thesis (Doctorate degree in Languages and Literatures) Faculty of Philosophy, Languages and Literatures, and Humanities, University of São Paulo, São Paulo, Brazil. 2017. Available at: http://www.teses.usp.br/teses/disponiveis/8/8147/ tde-07082017-162157/pt-br.php. Access on: 15 June 2020.

MATSUDA, A. Preparing teachers to teach English as an international language. Bristol: Multilingual Matters, 2017.

MCCARTNEY, H.; HARRIS, T. The image of the child constructed and transformed by preservice teachers in international contexts. Action in Teacher Education, [S.I.], v. 36, n. 4, p. 264-82, 2014.

MCKAY, S.; BOKHORST-HENG, W. International English in its sociolinguistic contexts. New York: Routledge, 2008.

MENEZES DE SOUZA, L. M. Multiliteracies and transcultural education. In: GARCIA, O.; FLORES, N.; SPOTTI, M. (Ed.). The Oxford Handbook of language and society. Oxford: University Press, 2017.

MORGAN, B.; MARTIN, I. Towards a research agenda for classroom-as-ecosystem. Modern Language Journal, [S.I.], v. 98, n. 2, p. 667-70, 2014.

MOTHA, S. Race, empire, and English language teaching: creating responsible and ethical anti-racist practice. New York, EUA: Teachers College Press, 2014. (Multicultural Education Series).

MOURA, G. Um olhar para a formação de um professor de língua inglesa em contexto transnacional/transcultural: Brasil-Canadá-Cuba. 2017. Dissertation (Masters of Languages and Literatures)-State University of Mato Grosso do Sul, Campo Grande, MS, Brazil, 2017.

OCHOA, A. International education in higher education: a developing process of engagement in teacher preparation programs. Teaching Education, [S.I.], v. 21, n. 1, p. 103-12, 2010. 
PARR, G. Leading an international teaching practicum: negotiating tensions in a site of border pedagogy. Asia-Pacific Journal of Teacher Education, [S.I.], v. 40, n. 2, p. 97-109, Apr. 2012. Available at: https://doi.org/10.1080/1359866X.2012.669824.

PENNYCOOK, A. The cultural politics of English as an international language. New York: Routledge, 2017.

PENNYCOOK, A. Language and mobility: unexpected places. Bristol: Multilingual Matters, 2012.

PENNYCOOK, A. Global Englishes and transcultural flows. New York: Routledge, 2007.

ROCHA, C. H.; MACIEL, R. F. Língua estrangeira e formação cidadã: entre discursos e práticas. Campinas, SP: Pontes, 2013.

SANTORO, N. Teaching in culturally diverse contexts: what knowledge about 'self' and 'others' do teachers need? Journal of Education for Teaching, [S.I.], v. 35, n. 3, p. 33-45, 2009.

SANTORO, N. 'Outsiders' and 'others': 'different' teachers teaching in culturally diverse classrooms. Teachers and Teaching: Theory and Practice, [S.I.], v. 13, n. 1, p. 81-97, 2007.

SANTORO, N.; MAJOR, J. Learning to be a culturally responsive teacher through international study trips: transformation or tourism? Teaching Education, [S.I.], v. 23, n. 3, p. 309-22, 2012.

WALTERS, L. M.; GARII, B.; WALTERS, T. Learning globally, teaching locally: incorporating international exchange into pre-service teacher training. Intercultural Education, [s.l.], v. 20, n. 1, p. 151-8, 2009.

\section{About the authors:}

Gustavo Moura: PhD Candidate, Faculty of Education, University of Manitoba. E-mail: gustavo.moura@umanitoba.ca, Orcid: https://orcid.org/0000-0002-5714-9581

Brian Morgan: Senior Scholar, Glendon College/York University. E-mail: bmorgan@glendon.yorku.ca, Orcid: https://orcid.org/0000-0002-2496-167X

\section{Received on March 13th, 2019.} Approved on May 15th, 2020. 